\title{
The evolution of pulmonary pathology in fatal COVID-19 disease: an autopsy study with clinical correlation
}

\author{
Hans Bösmüller ${ }^{1}$ (D) $\cdot$ Selina Traxler ${ }^{1} \cdot$ Michael Bitzer $^{2} \cdot$ Helene Häberle $^{3} \cdot$ Wolfgang Raiser $^{4} \cdot$ Dominik Nann $^{1}$. \\ Leonie Frauenfeld ${ }^{1} \cdot$ Antonio Vogelsberg $^{1} \cdot$ Karin Klingel $^{1} \cdot$ Falko Fend $^{1}$
}

Received: 13 May 2020 / Revised: 28 May 2020 / Accepted: 21 June 2020 / Published online: 30 June 2020

(C) The Author(s) 2020

\begin{abstract}
The pandemia of coronavirus disease 2019 (COVID-19) has caused more than 355,000 confirmed deaths worldwide. However, publications on postmortem findings are scarce. We present the pulmonary findings in four cases of fatal COVID-19 with a spectrum of lung pathology reflecting disease course and duration, invasive therapies, and laboratory features. Early disease is characterized by neutrophilic, exudative capillaritis with microthrombosis and high levels of IL-1beta and IL-6. Later stages are associated with diffuse alveolar damage and ongoing intravascular thrombosis in small to medium-sized pulmonary vessels, occasionally with areas of infarction equivalents, accompanied by laboratory features of disseminated intravascular coagulation. In late stages, organizing pneumonia with extensive intra-alveolar proliferation of fibroblasts and marked metaplasia of alveolar epithelium can be observed. Viral RNA is encountered in the lung, with virus particles in endothelial cells and pneumocytes. In many patients, multi-organ failure with severe liver damage sets in finally, possibly as consequence of an early-onset proinflammatory cytokine storm and/or thrombotic microangiopathy.
\end{abstract}

Keywords COVID-19 $\cdot$ Autopsy $\cdot$ Lung $\cdot$ Capillaritis $\cdot$ Microthrombosis

\section{Introduction}

Since the outbreak of coronavirus disease 2019 (COVID-19) caused by the novel coronavirus SARS-CoV-2 in December 2019, almost 5.6 million people have been infected during the

Karin Klingel and Falko Fend authors share senior authorship

This article is part of the Topical Collection on Quality in Pathology

Electronic supplementary material The online version of this article (https://doi.org/10.1007/s00428-020-02881-x) contains supplementary material, which is available to authorized users.

Hans Bösmüller

hans.boesmueller@med.uni-tuebingen.de

1 Department of Pathology and Neuropathology, University Hospital Tübingen and Eberhard Karls University Tübingen,

Liebermeisterstraße 8, 72076 Tübingen, Germany

2 Department of Internal Medicine I, University Hospital Tübingen, Tübingen, Germany

3 Department of Anaesthesiology, University Hospital Tübingen, Tübingen, Germany

4 Office for General Medicine, Tübingen, Germany course of the pandemia so far, and more than 355,000 succumbed to the disease [1]. Severe pneumonitis advancing to acute respiratory distress syndrome (ARDS), frequently associated with multi-organ failure, has been observed as the main clinical feature in fatal cases, with a case fatality rate of $1-4 \%[2,3]$. Despite the massive scale of the pandemia, published data on autopsy findings are limited [4-8]. In addition to diffuse alveolar damage, severe endothelial injury, disseminated intravascular coagulation, and a pro-inflammatory cytokine storm are considered main pathogenic factors in severe disease $[4,9]$. Early autopsy studies documented respiratory failure due to ARDS as predominant cause of death, frequently accompanied by capillary microthrombosis, superimposed bronchopneumonia, pulmonary thromboembolism, and signs of multi-organ failure with shock organs [8]. Most but not all patients with fatal outcome are elderly and show a variety of risk factors and comorbidities, including current smoking, chronic obstructive pulmonary disease, congestive heart failure, coronary artery disease, and diabetes mellitus $[3,10,11]$. Since the beginning of the epidemic in Germany, we have performed autopsies of confirmed COVID-19 cases at the Institute of Pathology, University Hospital Tuebingen, Germany. In the four cases presented here, we focus on the 
correlation between the autopsy findings, clinical course, and laboratory findings and demonstrate that the range of pulmonary pathology encountered reflects the duration of the disease, underlying pathophysiological mechanisms, type and intensity of treatment, and preexisting conditions.

\section{Methods}

\section{Autopsy}

For all deceased patients, informed consent had been obtained from the next of kin, and autopsies were performed following proposed guidelines for hazard group 3 pathogens, concerning autopsy practice and personal protective equipment $[7,12]$. In order to minimize risk, aerosol formation was avoided as much as possible, and craniotomy and dissection of the central nervous system were not performed. Both lungs were submerged in and filled with buffered formalin. All major parenchymal organs were extensively sampled for histology. In addition, specimens of both lungs, heart tissue, skeletal muscle, and liver were obtained for virological studies and electron microscopy.

\section{Histology and Immunostaining}

Routine histological stains were performed on formalin-fixed and paraffin-embedded samples following standard protocols. Immunohistochemistry was performed on an automated immunostainer (Ventana Benchmark Ultra, Roche Diagnostics, Mannheim, Germany).

\section{Electron microscopy}

For electron microscopy, tissues were fixed in $2.5 \%$ glutaraldehyde (Paesel-Lorei, Frankfurt, Germany) buffered in $0.1 \mathrm{M}$ cacodylate buffer ( $\mathrm{pH}$ 7.4). Tissues were postfixed in $1 \%$ $\mathrm{OsO}_{4}$ in $0.1 \mathrm{M}$ cacodylate buffer and then dehydrated in an ethanol series $(50,70,96,100 \%)$. The $70 \%$ ethanol was saturated with uranyl acetate for contrast enhancement. The specimens were embedded in Araldite (Serva, Heidelberg, Germany). Ultrathin sections were contrasted with lead citrate and analyzed and documented with an EM10A electron microscope (Carl Zeiss, Oberkochen, Germany).

\section{RNA studies for SARS-Cov-2 RNA and IL-1beta and IL- 6 mRNA detection}

The details for the quantitative RT-PCR studies for the detection of SARS-CoV-2 and IL-1beta and IL-6 mRNAs are described in the supplement.

\section{Results}

\section{Clinical histories}

Details on the patients are listed in Table 1. Selected laboratory parameters during the disease course are shown in Fig. 1 and supplementary Fig. 1. All patients had tested positive for SARS-CoV-2 by qRT-PCR at diagnosis in a throat swab.

Patient 1 was a 78-year-old obese female (BMI $35.2 \mathrm{~kg} / \mathrm{m}^{2}$ ) with hypertension and an atrioventricular block treated with a permanent dual chamber pacemaker. The patient died at home, after experiencing a 12-h period of fever with cough and vomiting according to her relatives. A throat swab performed few hours before death tested positive for SARS-CoV2 by qRT-PCR. No other laboratory data were available. Clinical autopsy was requested by her relatives and was undertaken $48 \mathrm{~h}$ after death.

Patient 2 was a 78 -year-old male patient with history of general weakness for 3 weeks, fever, and dry cough with worsening symptoms during the last 3 days before admission. The past medical history included coronary artery disease, hypertension, diabetes, and Parkinson's disease (BMI $28.4 \mathrm{~kg} / \mathrm{m}^{2}$ ). At admission, his blood pressure was $167 /$ $74 \mathrm{mmHg}$, body temperature $36.2^{\circ} \mathrm{C}$, respiratory rate 20 / min, and $\mathrm{SpO}_{2} 92 \%$ breathing ambient air. Laboratory results showed lymphopenia of $940 / \mu l$ (normal $1.100-3.200$ ), increased D-dimer with $0.87 \mu \mathrm{g} / \mathrm{ml}(<0.5)$, fibrinogen $574 \mathrm{mg} / \mathrm{dl}$ (170-410), C-reactive protein (CRP) $29.5 \mathrm{mg} / \mathrm{dl}$ $(\leq 0.5)$, IL-6 $100 \mathrm{ng} / \mathrm{l}(0-4)$, LDH with $479 \mathrm{U} / 1(\leq 250)$ creatine kinase $280 \mathrm{U} / \mathrm{l}(\leq 190)$, and ferritin $113 \mu \mathrm{g} / \mathrm{dl}$ (3-30) (see also supplementary Fig. 1). He was transferred to the ICU the next day with worsening respiratory symptoms, including a respiratory rate of $38 / \mathrm{min}$ and $\mathrm{SpO}_{2} 91 \%$ under $\mathrm{O}_{2} 6 \mathrm{l} / \mathrm{min}$. He was intubated due to respiratory failure. Several blood cultures for bacteria or fungi remained negative. Overall organ function improved in the next 2 days. At that point in time, IL-6 and D-dimer concentrations peaked at $3.300 \mathrm{ng} / \mathrm{l}$ and $19 \mu \mathrm{g} / \mathrm{ml} \mathrm{FEU}$ respectively, whereas thrombocytopenia worsened despite anticoagulation. Within the following $24 \mathrm{~h}$, the patient developed multi-organ failure and vasoplegic shock. Leukocytes, procalcitonin, and CRP concentrations were increasing continuously despite lack of evidence for superinfection, whereas D-dimer and IL-6 concentrations dropped (see supplementary Fig. 1). The patient died 4 days after peak of Ddimer concentration due to vasoplegic shock and liver failure despite vasopressor and organ replacement therapy. The autopsy was performed within $24 \mathrm{~h}$ after death.

Patient 3 was a 72-year-old male admitted with syncope, fever, cough, and emesis. The past medical history included coronary artery disease, hypertension, currently untreated polymyalgia rheumatica, and a history of Merkel cell carcinoma with ongoing local adjuvant radiotherapy (BMI $22.3 \mathrm{~kg} /$ $\mathrm{m}^{2}$ ). At admission, his blood pressure was $95 / 60 \mathrm{mmHg}$, body 
Table 1 Clinical data of the patients

\begin{tabular}{|c|c|c|c|c|c|c|}
\hline Age & Sex & $\begin{array}{l}\text { Days from admission } \\
\text { until death }\end{array}$ & $\begin{array}{l}\text { Days in } \\
\text { ICU }\end{array}$ & $\begin{array}{l}\text { Days on } \\
\text { dialysis }\end{array}$ & Comorbidities & $\begin{array}{l}\text { Clinical cause of } \\
\text { death }\end{array}$ \\
\hline 78 & $\mathrm{w}$ & 1 (home care) & - & - & Cardiac pacemaker, obesity & Pneumonia \\
\hline 79 & $\mathrm{~m}$ & 9 & 8 & 3 & $\begin{array}{l}\text { Coronary heart disease, diabetes type } 2 \text {, obesity, hypertension, } \\
\text { Parkinson's syndrome }\end{array}$ & $\begin{array}{l}\text { ARDS, liver } \\
\text { failure, shock }\end{array}$ \\
\hline 72 & $\mathrm{~m}$ & 16 & 11 & 6 & $\begin{array}{l}\text { Coronary heart disease, Merkel cell carcinoma under adjuvant } \\
\text { radiotherapy, obesity, polymyalgia rheumatica }\end{array}$ & $\begin{array}{l}\text { ARDS, liver } \\
\text { failure, shock }\end{array}$ \\
\hline 59 & M & 35 & $\begin{array}{l}35(24 \text { on } \\
\text { ECMO) }\end{array}$ & 24 & Hypertension, intrinsic asthma & $\begin{array}{l}\text { ARDS, } \\
\text { multi-organ } \\
\text { failure }\end{array}$ \\
\hline
\end{tabular}

$I C U$ intensive care unit, $A R D S$ acute respiratory distress syndrome, ECMO extracorporeal membrane oxygenation

temperature $38.3{ }^{\circ} \mathrm{C}$, respiratory rate $10 / \mathrm{min}$, and $\mathrm{SpO}_{2} 95 \%$ breathing ambient air. Laboratory results showed lymphopenia with 440/ $\mu \mathrm{l}$, increased CRP $7.7 \mathrm{mg} / \mathrm{dl}(\leq 0.5)$ and IL-6 $27 \mathrm{ng} / \mathrm{l}(0-4)$, and normal values for LDH, ALT/AST, bilirubin, and D-dimer (see Fig. 1). He was transferred to the ICU 4 days later with worsening respiratory symptoms and recurrent fever episodes and was intubated. Several blood cultures for bacteria remained negative. Oxygenation improved until day 6 day after ICU admission, when acute hypercapnia became apparent. Marked leukocytosis and increase in D-dimer, C-reactive protein, IL-6, and procalcitonin levels developed. Pulmonary superinfection with Klebsiella oxytoca was diagnosed, and meropenem therapy was started. The patient subsequently developed renal and liver failure, and IL-6 and Ddimer levels decreased. Renal replacement therapy was initiated, but he expired 10 days after admission to ICU due to liver failure. The autopsy was performed within $24 \mathrm{~h}$ after death.

Patient 4 was an obese 59-year-old male with a history of intrinsic asthma and hypertension (BMI $35.8 \mathrm{~kg} / \mathrm{m}^{2}$ ). He complained about respiratory symptoms for 2 weeks prior to admission. He was admitted to the ICU of a peripheral hospital and transferred to our hospital 6 days later for his respiratory failure and started on extracorporeal membrane oxygenation (ECMO). In addition, he underwent dialysis. During the course of his disease, he experienced two episodes with marked increase in D-dimer levels, the second 4 days before his death. He expired due to terminal ARDS and multi-organ failure 6 weeks since the beginning of his symptoms. The autopsy was performed within $24 \mathrm{~h}$ after death.

\section{Autopsy findings}

Details on the organ weights (formalin-fixed) are listed in supplementary Table 1.

Patient 1 Grossly, lungs showed significant pulmonary edema with slightly increased consistency of lower lobes. No focal changes were observed on cut surfaces of the lung. The heart showed an increased weight of $520 \mathrm{~g}$ and biventricular dilation. Sclerosis of the coronary arteries or signs of ischemia in the hyperplastic myocardium were not observed. All other organs were normal upon gross inspection.

Histologically, in addition to marked generalized pulmonary edema, the lower lobes showed florid capillary endotheliitis with increased neutrophils, formation of microthrombi in alveolar capillaries, and small pulmonary vessels, including septal veins. In addition, focal inflammatory exudate with neutrophils and sparse hyaline membranes with incipient organizing changes but without hyperplasia of alveolar epithelium were observed (Fig. 2). The liver showed moderate acute congestion and activation of Kupffer cells but lacked inflammatory infiltrates. qRT-PCR of cytokines in lung tissue revealed a massive increase of IL-1beta and IL-6 mRNA. Early pneumonitis with thrombotic microangiopathy resulting in inflammation-associated pulmonary edema and acute cardiac failure was considered the likely cause of death.

Patient 2 Gross inspection showed marked pulmonary edema, consolidation of both lower lobes and macroscopically visible thrombi mainly in small to medium-sized pulmonary vessels, both arteries and veins, in part accompanied by areas of fresh infarction (Fig. 3a, c). Moderate hepatosplenomegaly was observed, and the other organs were inconspicuous.

The lung revealed diffuse alveolar damage with extensive intra-alveolar fibrin deposits with formation of hyaline membranes, marked hyperplasia and desquamation of alveolar epithelium, and accumulation of macrophages with frequent multinuclear giant cells (Figs. 3b, d and 4a). Especially the lower lobes showed areas of organized diffuse alveolar damage (DAD) with proliferation of fibroblasts and early collagen fiber deposits within the intra-alveolar exudate. A striking finding was a focally massive accumulation of leukocytes in medium-sized vessels, but florid neutrophilic capillaritis was absent. The liver showed significant activation of macrophages with signs of hemophagocytosis, but no necrosis or inflammatory infiltrates. Electron microscopy demonstrated viral particles in pulmonary endothelial cells and also in 
CRP

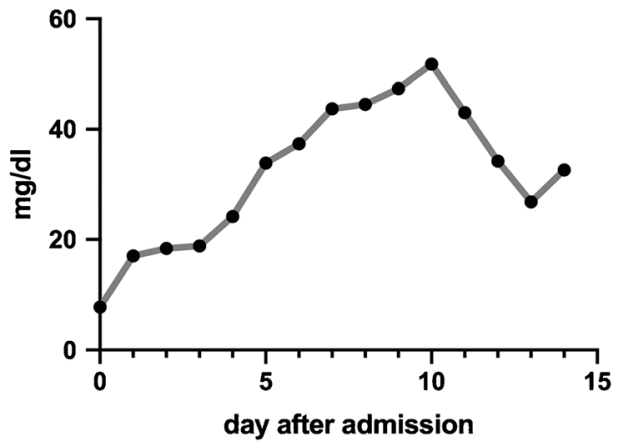

D-Dimer

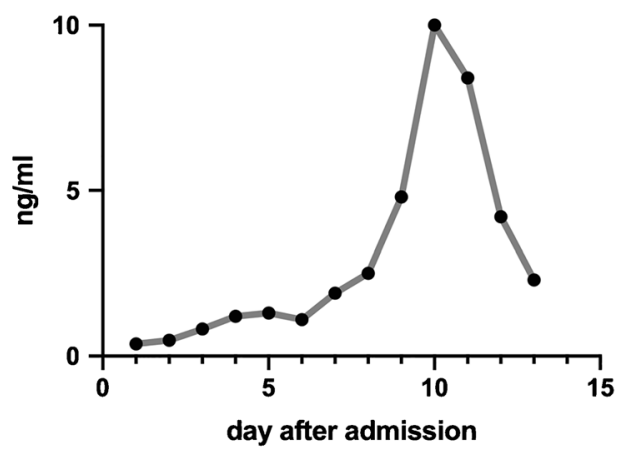

Ferritin

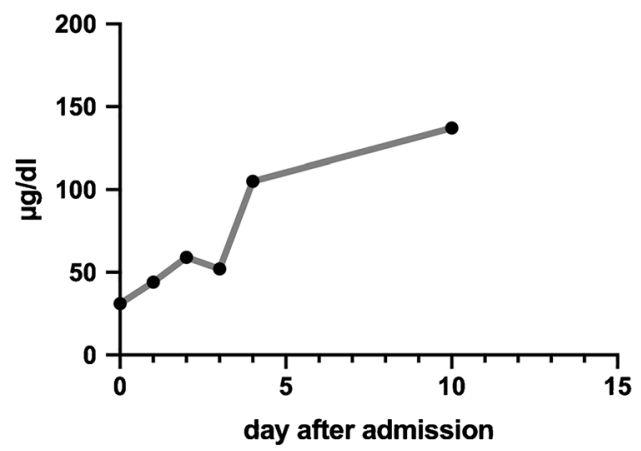

AST

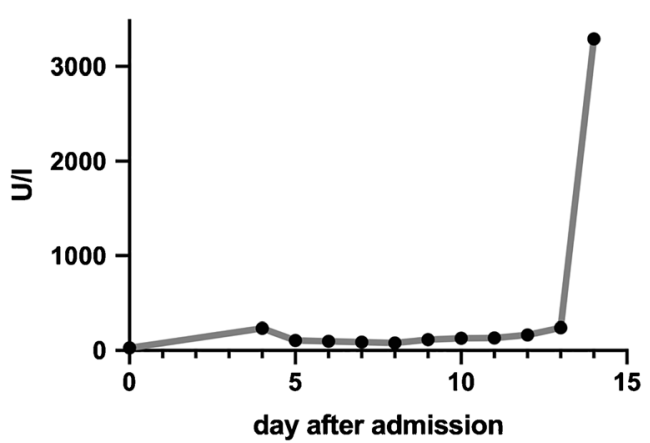

Procalcitonin

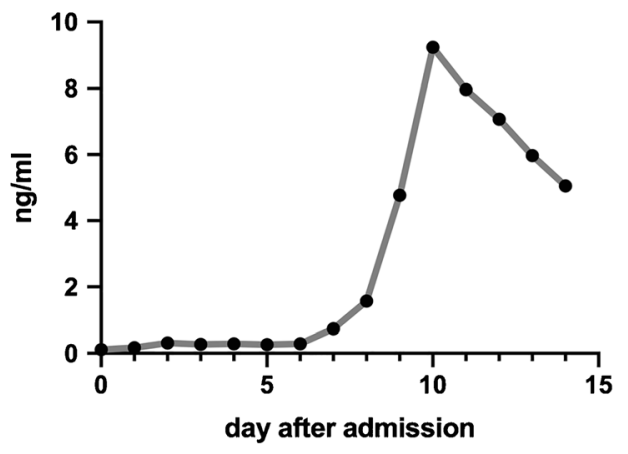

IL-6

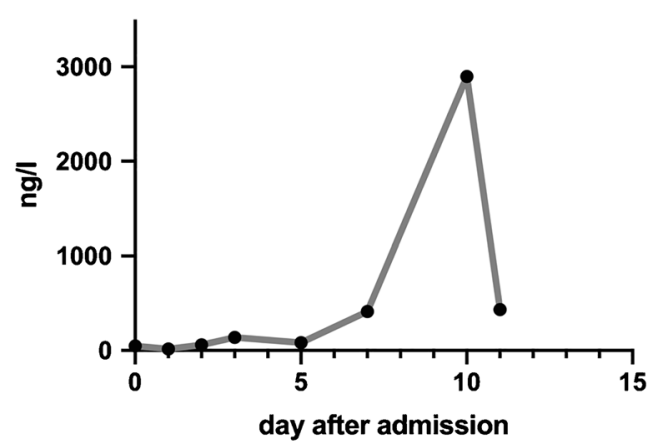

Bilirubin

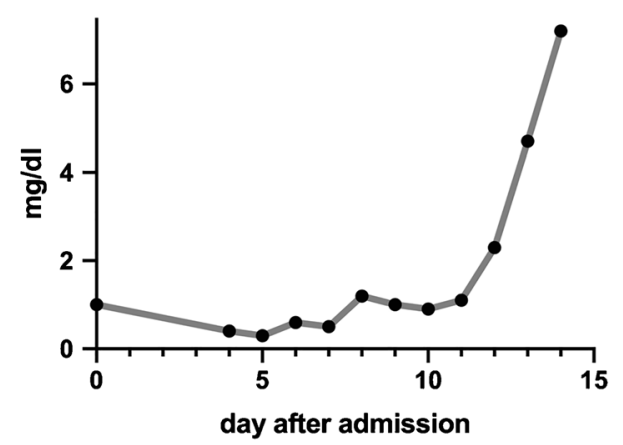

ALT

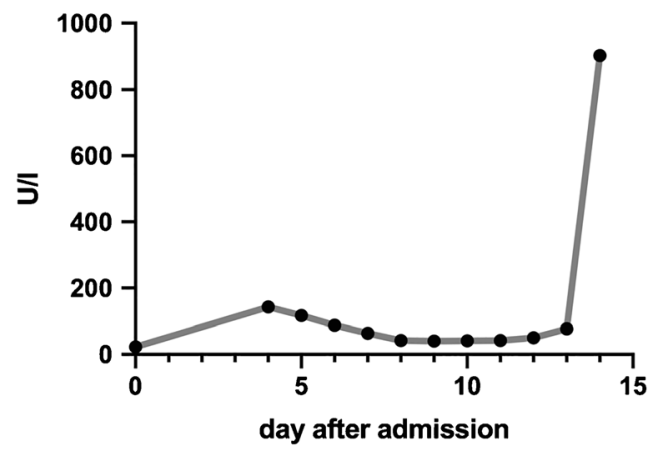

Fig. 1 Laboratory data patient 3 
pneumocytes type 1 (Fig. 4b and supplementary Fig. 2). IL1beta and IL-6 mRNA were not increased in lung tissue.

Patient 3 Gross and microscopic pulmonary changes were similar to patient 2 , with macroscopically identifiable thrombi in pulmonary vessels and consolidation of both lower lobes. The liver showed enlargement with yellowish tan surface, and splenomegaly was present. Pulmonary histology showed changes of advanced diffuse alveolar damage, with extensive hyaline membranes and intra-alveolar macrophage accumulations with multiple giant cells and pronounced, in part atypical hyperplasia of alveolar epithelium with focal squamous metaplasia and areas of organizing pneumonia (Fig. 4) Neutrophils were infrequent, arguing against significant bacterial superinfection. Viral particles were observed in endothelial cells of lung capillaries and also in vacuoles within the interstitial space (Fig. 4b). IL-1beta and IL-6 mRNA were not increased in lung tissue.

Patient 4 Demonstrated lungs with massively increased weight (left, $828 \mathrm{~g}$; right, $1032 \mathrm{~g}$ ) and significant consolidation in both upper and lower lobes. In addition to cardiomegaly with a heart weight of $590 \mathrm{~g}$ and signs of liver damage, he revealed intestinal mucositis and hemorrhage, probably responsible for the second increase in D-dimers.

Histologically, the lungs showed the aspect of longstanding ARDS in organizing stage with extensive fibrinous

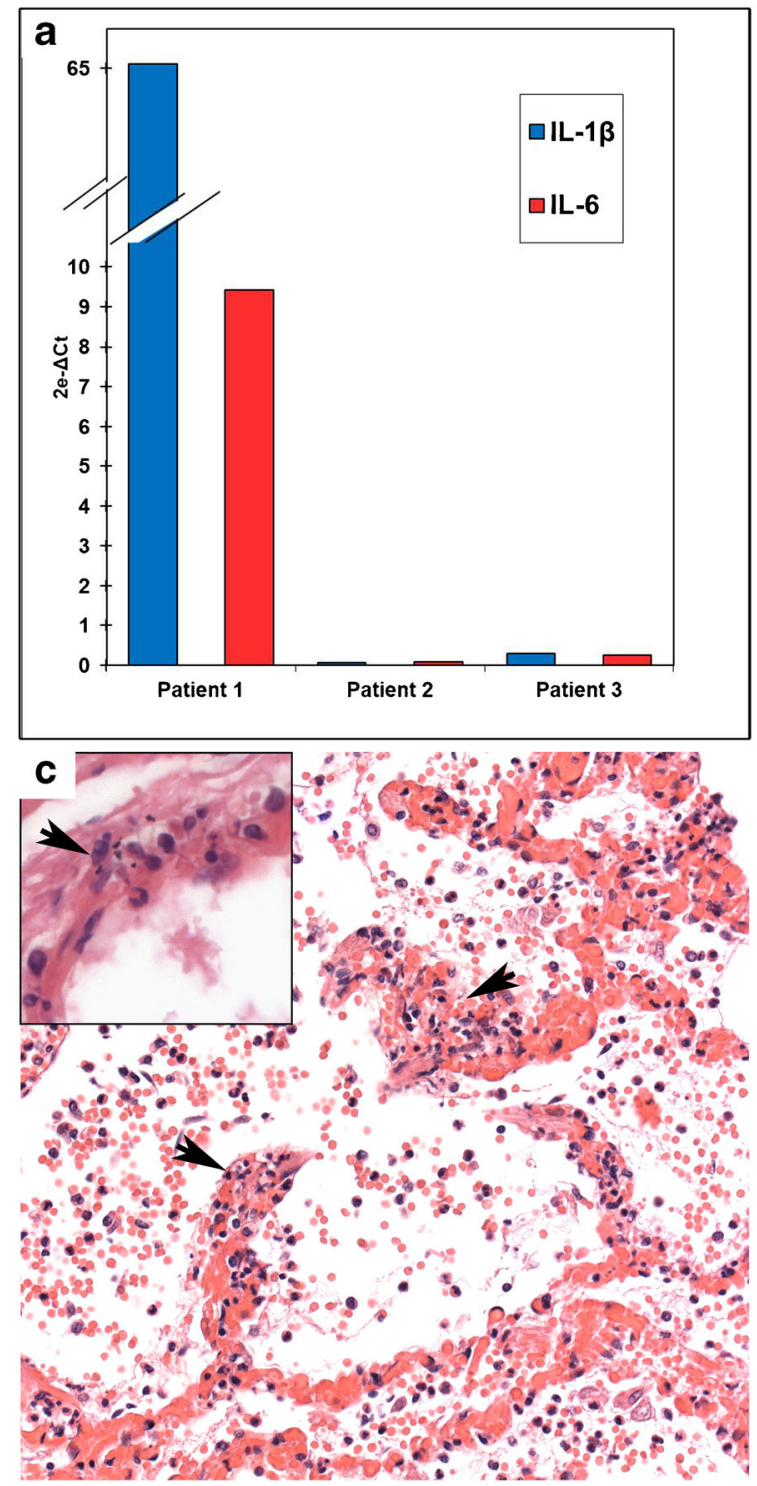

Fig. 2 Patient 1. a Significant increase of IL-1beta and IL-6 mRNA in lung tissue of patient 1 as compared with patients 2 and 3. b Neutrophilic septal capillaritis (arrowheads) with associated intra-alveolar edema. H\&E $(\times 200)$. The insert shows nuclear dust in higher magnification. $\mathbf{c}$ Neutrophilic capillaritis associated with microthrombosis (arrowheads)

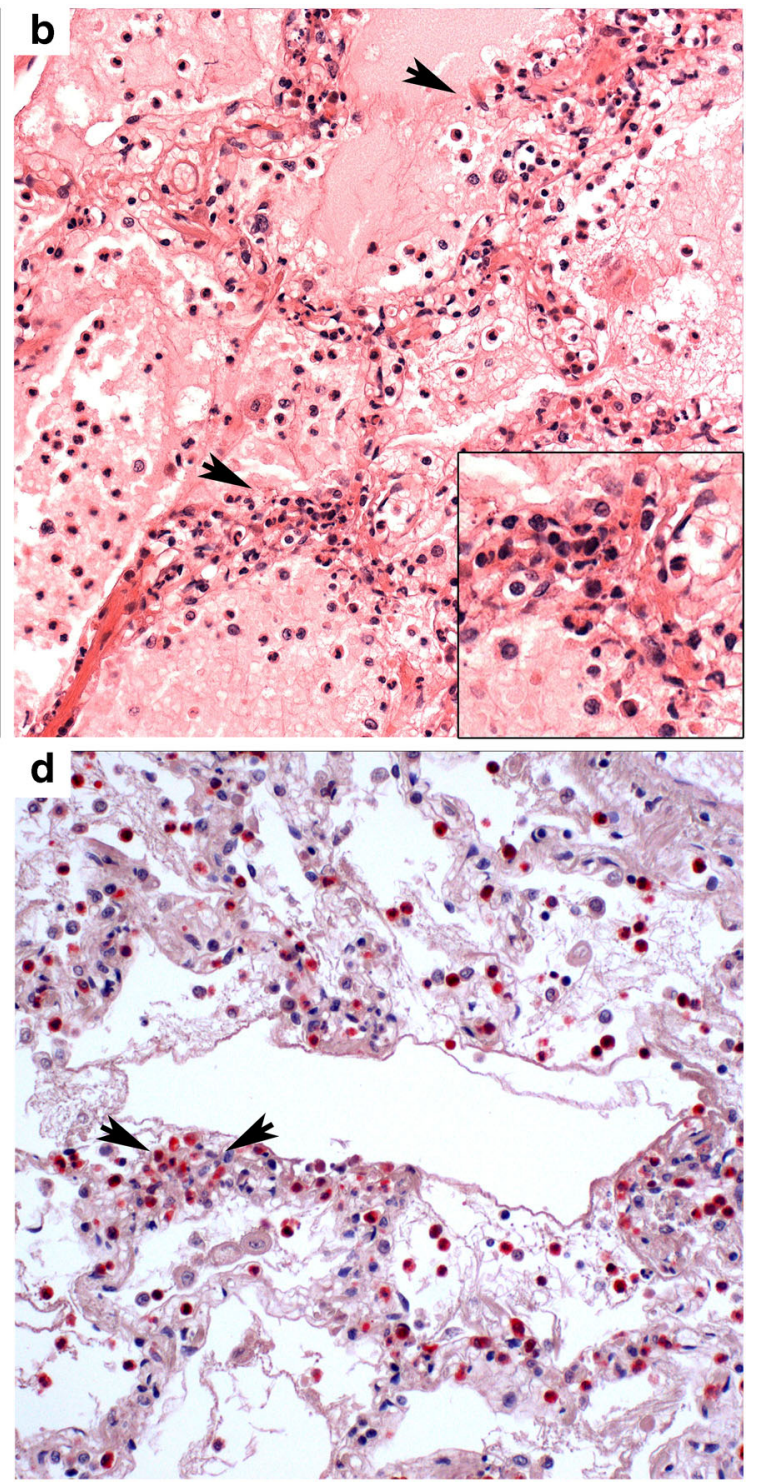

and intra-alveolar hemorrhage. H\&E $(\times 200)$. The insert shows endothelial necrosis with nuclear dust (arrow) and transmigration of neutrophils $(\times 400)$. d NASD chloroacetate esterase histochemistry highlights intraund perivascular accumulation of neutrophils (granulocytes appear red) $(\times 200)$ 

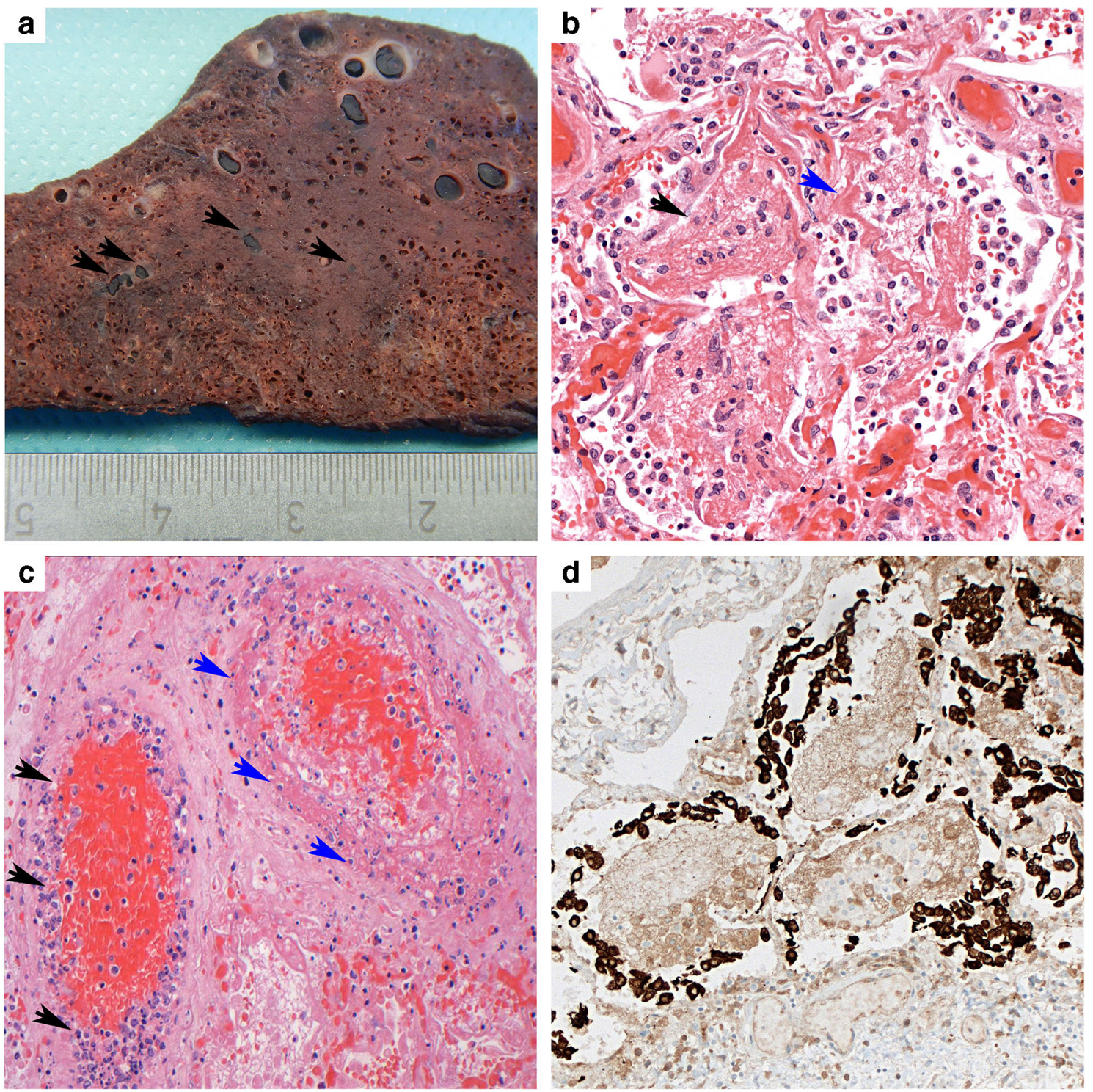

Fig. 3 Patient 2. a Gross image of cut surface of the lower pulmonary lobe with multiple thrombi in small vessels, focally accompanied by perifocal hemorrhage (arrows) and consolidation and discoloration of the parenchyma. b The lower lobes show advanced diffuse alveolar damage with fibrinous exudate (black arrowheads), hyaline membranes (blue arrowheads), incipient hyperplasia of alveolar epithelium, and increased desquamation of macrophages. H\&E $(\times 200)$. c Thrombosis of two

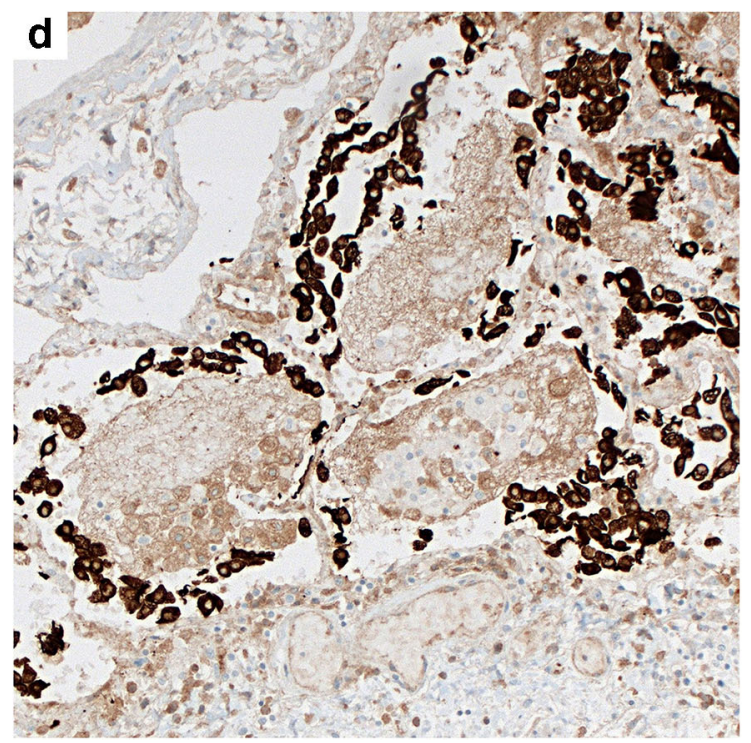

medium-sized pulmonary blood vessels with marked endotheliitis (black arrowheads), fibrinoid necrosis of the vessel wall (blue arrowheads), and thrombi in engorged surrounding capillaries. H\&E $(\times 200)$. d Massive hyperplasia of type 2 pneumocytes surrounding the fibrinous exudate with macrophages. Pan-cytokeratin (AE1/3) immunohistochemical stain $(\times 200)$

exudates, diffuse thickening of alveolar septae, massive hyperplasia of alveolar and bronchial epithelium with focal squamous metaplasia, and typical concentrically layered plugs of loose connective tissue with central aggregates of inflammatory cells (Fig. 4c, d).

\section{Detection of viral RNA}

Significant levels of SARS-CoV-2 RNA were detected in the lungs of all patients by qRT-PCR, but not in the livers and hearts. Details are summarized in supplementary Table 2.

\section{Discussion}

Autopsies are an important tool to investigate the pathogenetic mechanisms of severe SARS-CoV-2 infection by demonstrating morphological changes and other important features such as infected cell types and viral load in organs normally not accessible in severely ill patients. The four cases presented here highlight a range of pulmonary alterations with variable severity, which reflect different stages of disease evolution. Patients 2, 3, and 4 demonstrated extensive, advanced pulmonary changes typical for ARDS, leaving no doubt about the severity of lung damage, accompanied by advanced 


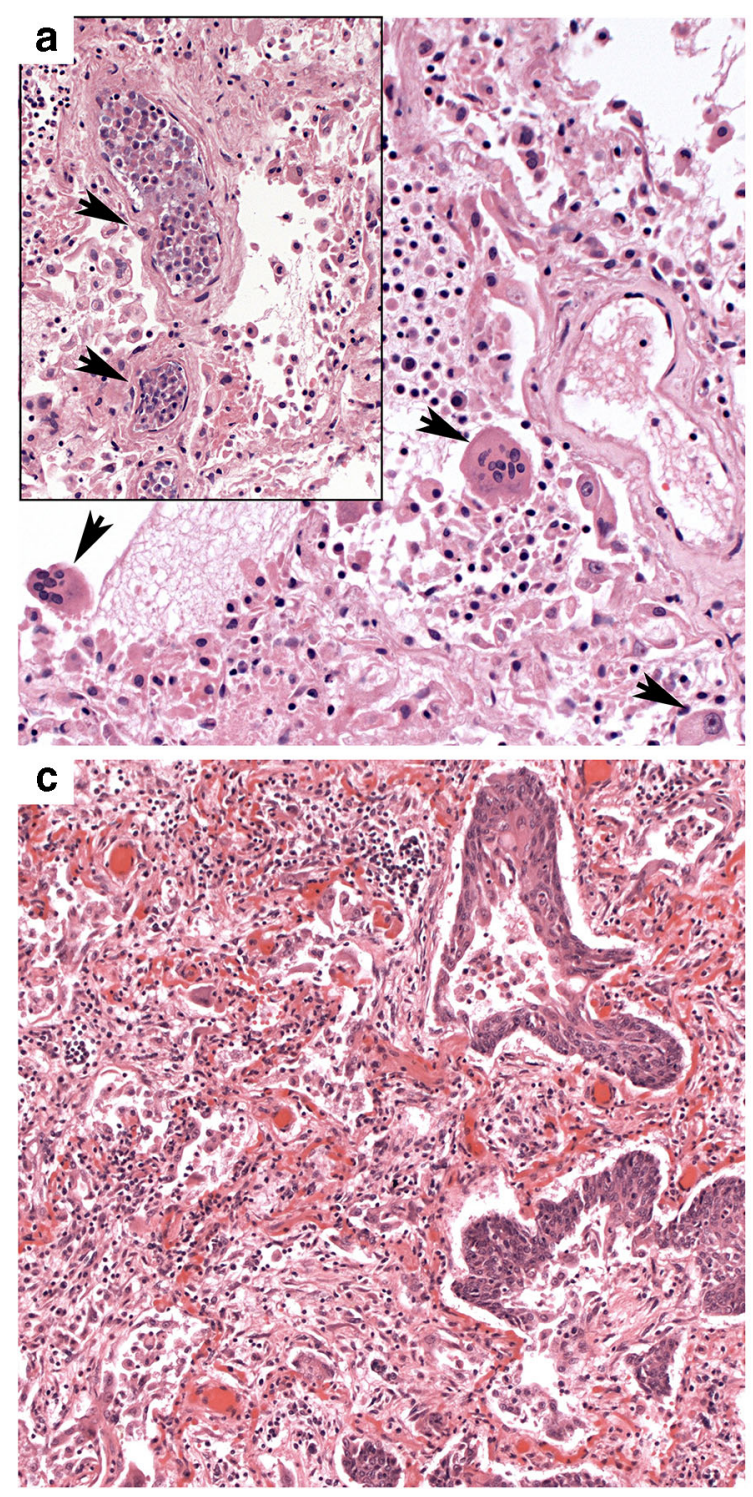

Fig. 4 Patients 3 and 4. Patient 3. a Lower lobe with diffuse alveolar damage with multinuclear alveolar macrophages (arrows) and striking leukostasis (insert), both $\mathrm{H} \& \mathrm{E}(\times 200)$. b Virus particles (red arrowhead) are often found in endothelial cells (white arrowhead, erythrocyte; gray arrowhead, nucleus of endothelial cell); insert bottom, bar scale $100 \mathrm{~nm}$. The majority of viruses are located in membrane-bound compartments,

organizing changes in patient four, reflecting the prolonged clinical course. In contrast, patient 1 showed early changes with striking increases of IL1-beta and IL-6 mRNA, neutrophilic capillaritis, and capillary microthrombosis but relatively little parenchymal inflammation. Based on conventional criteria, respiratory insufficiency therefore might be considered unlikely direct cause of death, but this case and recently published autopsy data indicate that pulmonary microvascular changes are an important and distinguishing feature of COVID-19 and may contribute to hypoxemia and acute cardiac insufficiency. It is important to distinguish these findings from mere stress-related neutrophilia, which lacks microthrombus formation and presence of widespread, in part

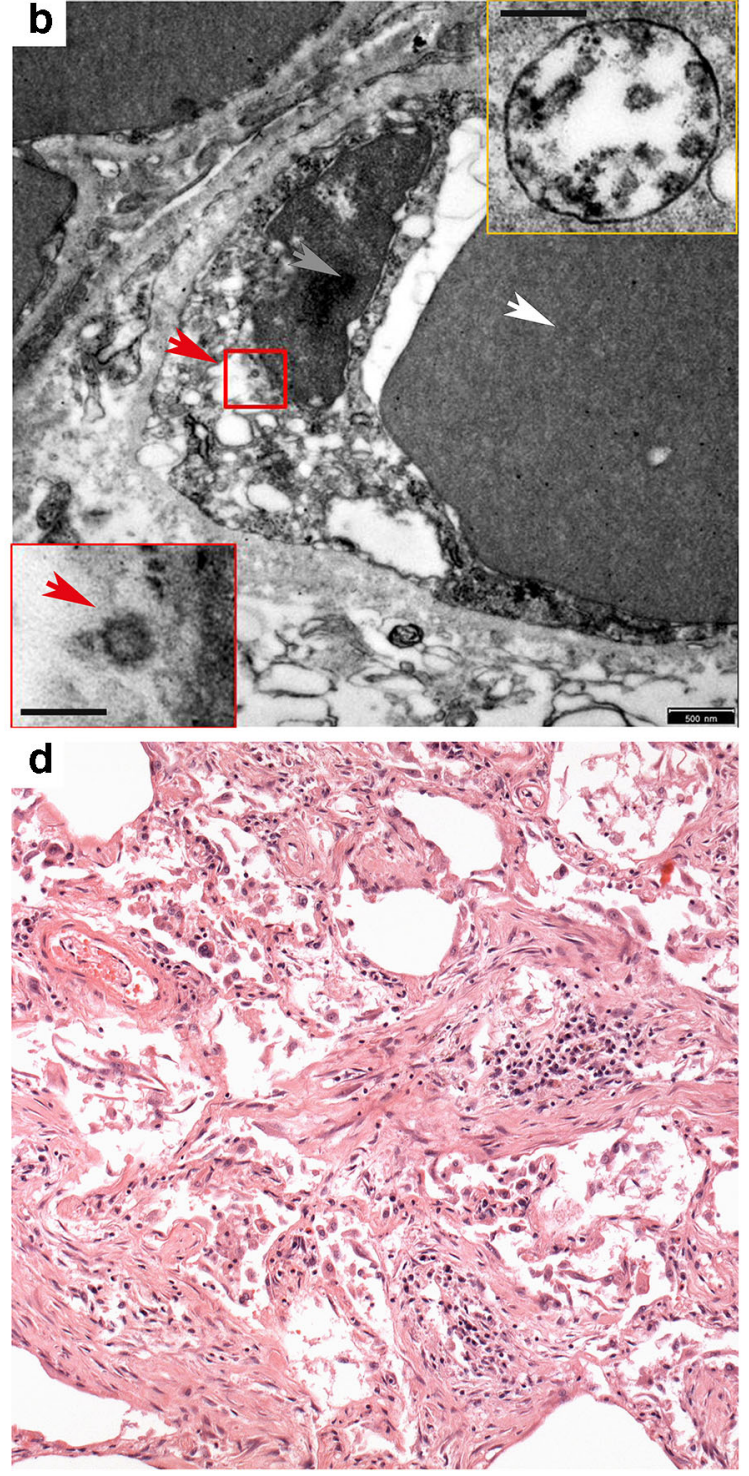

likely representing endosomes, insert top (bar scale $200 \mathrm{~nm}$ ). Patient 4 . c The lung shows features of prolonged ARDS with extensive epithelial hyperplasia and focal squamous metaplasia. H\&E $(\times 100)$. d Typical changes of organizing pneumonia with plugs of loose connective tissue with concentrically arranged fibroblasts and central accumulation of inflammatory cells filling alveolar spaces. H\&E $(\times 100)$

directly virus-induced endothelial damage [13]. Irrespective of the severity of pulmonary changes, however, all 4 patients showed SARS-CoV-2 RNA in lung tissues but failed to show detectable levels of viral RNA in other organs studied. The entry of SARS-CoV-2 into cells of the host is mediated by angiotensin-converting enzyme 2 (ACE2), a membrane bound metallopeptidase with broad mRNA expression in human tissues, with high levels of protein detectable on alveolar epithelial cells, intestinal epithelium, and both arterial and venous endothelial cells $[14,15]$ and the cellular protease TMPRSS2 [16]. High levels of viral RNA in pulmonary tissues in our cases, together with the histological findings, indicate that direct virus-induced damage is centered on the 
lung. Of interest, cytokine mRNA levels were high in the lung of patient 1 with very short disease course, whereas no significant levels were detected in patients 2 and 3 , congruent with a drop in serum IL-6 levels before death. This could indicate that the massive secretion of cytokines occurs early in severe cases and might be a contributing factor to rapid disease evolution. The multi-organ failure observed in many patients is considered the result of a pro-inflammatory cytokine storm, including IL1 $\beta$, IL2, IL6, IL7, IL8, IL10, IL17, and interferon gamma, probably accompanied by diffuse macrophage activation, as also evidenced by the presence of hemophagocytosis in liver tissue of our patients [9].

A common feature of severe COVID-19 is massive hypercoagulability with prominent elevation of D-dimer and fibrin/ fibrin degradation products as in patients 2 and 3 [17-19]. This profound coagulopathy is considered responsible for the high incidence of thrombotic events and may be one reason for the high mortality in patients with cardiovascular risk factors and evidence of myocardial damage. Our autopsy findings support this contention, since endotheliitis with microthrombus formation and involvement of medium-sized vessels leading to pulmonary infarcts were prominent; however, obvious myocardial damage or lymphocytic inflammation was lacking. The neutrophilic capillaritis in patient 1 with short disease course indicates that severe endothelial damage due to viral infection, cytokines and induction of neutrophil extracellular traps (NETs) with endothelial apoptosis, and breakdown of the epithelial-endothelial barrier may be an early event in fatal cases $[4,6]$. The massive vascular inflammation occasionally also observed in medium-sized vessels as shown in Fig. 3 is unusual for viral pneumonia without bacterial superinfection and may be a discerning feature of severe COVID-19. The hypercoagulability may also contribute to the observed mortality by triggering cardiovascular events before the development of severe pulmonary disease [11, 20,21]. The frequent occurrence of pulmonary thromboembolism in fatal COVID-19 has recently been documented in an autopsy study $[7,8]$. We assume that the combination of NET formation with their known pro-thrombogenic features, cytokine priming, and direct viral cytopathic effect on endothelia can rapidly induce disseminated intravascular coagulation $[17,22$, 23].

In terms of risk factors and comorbidities, our four patients reflect the risk profiles observed during the pandemia $[3,11$, 20]. Obesity, diabetes, hypertension, and pulmonary and cardiovascular disease are highly prevalent in patients with severe or fatal SARS-CoV-2 infection $[3,10,11,20]$. The laboratory findings observed in patients 2 and 3 reflect common risk factors of fatal outcome, namely, lymphopenia; increased D-dimers; evidence of massive systemic inflammation including high levels of CRP, procalcitonin, and IL-6 during acute disease; and in the final stages massive ALT/AST elevation [1, $3,4,7,11,20]$. The liver damage observed in our patients is likely not due to local inflammation or direct cytopathic effects of SARS-CoV-2, given the absence of viral RNA, but probably is a combination of cytokine-induced, metabolic, and ultimately hypoxic damage, as evidenced by massive centroacinar necrosis in patient 3 [24].

\section{Conclusion}

Clinical autopsies promote our understanding of COVID-19 pathogenesis through assessment of tissue damage, virus distribution, and causes of death. In addition to severe pulmonary disease, disseminated coagulation and thrombus formation triggered by multifactorial endothelial damage are frequent events in fatal SARS-CoV-2 infection.

Authors' contributions HB (study design, autopsies, diagnostic pathology, writing of the manuscript), ST (molecular diagnostics), MB (clinical correlation/internal medicine, cases 2-4), HH (clinical correlation/ICU), WR (clinical correlation/general medicine, case 1), DN (diagnostic pathology, imaging cases 1-2), LF (diagnostic pathology, imaging cases $3-$ 4), AV (autopsies), KK (electron microscopy, evaluation of molecular diagnostics), FF (critical review, writing of the manuscript). All authors have read and approved the final version of the manuscript.

FundingInformation Open Access funding provided by Projekt DEAL.

Data availability All data and material available.

\section{Compliance with ethical standards}

Conflict of interest The authors declare that they have no conflict of interest.

Ethics approval For all deceased patients, informed consent had been obtained from the next of kin.

Consent to participate Not applicable.

Consent for publication Not applicable.

Code availability Not applicable.

Open Access This article is licensed under a Creative Commons Attribution 4.0 International License, which permits use, sharing, adaptation, distribution and reproduction in any medium or format, as long as you give appropriate credit to the original author(s) and the source, provide a link to the Creative Commons licence, and indicate if changes were made. The images or other third party material in this article are included in the article's Creative Commons licence, unless indicated otherwise in a credit line to the material. If material is not included in the article's Creative Commons licence and your intended use is not permitted by statutory regulation or exceeds the permitted use, you will need to obtain permission directly from the copyright holder. To view a copy of this licence, visit http://creativecommons.org/licenses/by/4.0/. 


\section{References}

1. Zhou P, Yang XL, Wang XG, Hu B, Zhang L, Zhang W, Si HR, Zhu Y, Li B, Huang CL, Chen HD, Chen J, Luo Y, Guo H, Jiang RD, Liu MQ, Chen Y, Shen XR, Wang X, Zheng XS, Zhao K, Chen QJ, Deng F, Liu LL, Yan B, Zhan FX, Wang YY, Xiao GF, Shi ZL (2020) A pneumonia outbreak associated with a new coronavirus of probable bat origin. Nature. 579:270-273

2. Guan WJ, Ni ZY, Hu Y, Liang WH, Ou CQ, He JX, Liu L, Shan H, Lei CL, Hui DSC, du B, Li LJ, Zeng G, Yuen KY, Chen RC, Tang CL, Wang T, Chen PY, Xiang J, Li SY, Wang JL, Liang ZJ, Peng YX, Wei L, Liu Y, Hu YH, Peng P, Wang JM, Liu JY, Chen Z, Li G, Zheng ZJ, Qiu SQ, Luo J, Ye CJ, Zhu SY, Zhong NS, China Medical Treatment Expert Group for Covid-19 (2020) Clinical characteristics of coronavirus disease 2019 in China. N Engl J Med 382:1708-1720

3. Zhou F, Yu T, Du R, Fan G, Liu Y, Liu Z et al (2020) Clinical course and risk factors for mortality of adult inpatients with COVID-19 in Wuhan, China: a retrospective cohort study. Lancet. 395:10541062

4. Barnes BJ, Adrover JM, Baxter-Stoltzfus A, Borczuk A, CoolsLartigue J, Crawford JM, Daßler-Plenker J, Guerci P, Huynh C, Knight JS, Loda M, Looney MR, McAllister F, Rayes R, Renaud S, Rousseau S, Salvatore S, Schwartz RE, Spicer JD, Yost CC, Weber A, Zuo Y, Egeblad M (2020) Targeting potential drivers of COVID-19: neutrophil extracellular traps. J Exp Med 217

5. Barton LM, Duval EJ, Stroberg E, Ghosh S, Mukhopadhyay S (2020) COVID-19 Autopsies. Oklahoma, USA. Am J Clin Pathol

6. Varga Z, Flammer AJ, Steiger P, Haberecker M, Andermatt R, Zinkernagel AS, Mehra MR, Schuepbach RA, Ruschitzka F, Moch H (2020) Endothelial cell infection and endotheliitis in COVID-19. Lancet. 395:1417-1418

7. Menter T, Haslbauer JD, Nienhold R, Savic S, Hopfer H, Deigendesch N, Frank S, Turek D, Willi N, Pargger H, Bassetti S, Leuppi JD, Cathomas G, Tolnay M, Mertz KD, Tzankov A (2020) Post-mortem examination of COVID19 patients reveals diffuse alveolar damage with severe capillary congestion and variegated findings of lungs and other organs suggesting vascular dysfunction. Histopathology.

8. Wichmann D, Sperhake JP, Lutgehetmann M, Steurer S, Edler C, Heinemann A et al (2020) Autopsy findings and venous thromboembolism in patients with COVID-19: a prospective cohort study. Ann Intern Med

9. Li H, Liu L, Zhang D, Xu J, Dai H, Tang N, Su X, Cao B (2020) SARS-CoV-2 and viral sepsis: observations and hypotheses. Lancet. 395:1517-1520

10. Mehra MR, Desai SS, Kuy S, Henry TD, Patel AN (2020) Cardiovascular disease, drug therapy, and mortality in Covid-19. $\mathrm{N}$ Engl J Med

11. Ruan Q, Yang K, Wang W, Jiang L, Song J (2020) Clinical predictors of mortality due to COVID-19 based on an analysis of data of 150 patients from Wuhan, China. In: Clinical predictors of mortality due to COVID-19 based on an analysis of data of 150 patients from Wuhan. China, Intensive Care Med

12. Hanley B, Lucas SB, Youd E, Swift B, Osborn M (2020) Autopsy in suspected COVID-19 cases. J Clin Pathol 73:239-242

13. Ackermann M, Verleden SE, Kuehnel M, Haverich A, Welte T, Laenger F, Vanstapel A, Werlein C, Stark H, Tzankov A, Li WW, Li VW, Mentzer SJ, Jonigk D (2020) Pulmonary vascular endothelialitis, thrombosis, and angiogenesis in Covid-19. N Engl J Med

14. Hoffmann M, Kleine-Weber H, Schroeder S, Kruger N, Herrler T, Erichsen S et al (2020) SARS-CoV-2 cell entry depends on ACE2 and TMPRSS2 and is blocked by a clinically proven protease inhibitor. Cell. 181:271-280 e8

15. Hamming I, Timens W, Bulthuis ML, Lely AT, Navis G, van Goor $\mathrm{H}$ (2004) Tissue distribution of ACE2 protein, the functional receptor for SARS coronavirus. A first step in understanding SARS pathogenesis. J Pathol 203:631-637

16. Ziegler C AS, Nyquist S, Mbano I, Miao V, et.al. SARS-CoV-2 receptor ACE2 is an interferon-stimulated gene in human airway epithelial cells and is detected in specific cell subsets across tissues. cell. 2020

17. Connors JM, Levy JH (2020) COVID-19 and its implications for thrombosis and anticoagulation. Blood. 135:2033-2040

18. Llitjos JF, Leclerc M, Chochois C, Monsallier JM, Ramakers M, Auvray M, Merouani K (2020) High incidence of venous thromboembolic events in anticoagulated severe COVID-19 patients. J Thromb Haemost

19. Spiezia L, Boscolo A, Poletto F, Cerruti L, Tiberio I, Campello E et al (2020) COVID-19-related severe hypercoagulability in patients admitted to intensive care unit for acute respiratory failure. Thromb Haemost

20. Ruan Q, Yang K, Wang W, Jiang L, Song J (2020) Correction to: clinical predictors of mortality due to COVID-19 based on an analysis of data of 150 patients from Wuhan. China, Intensive Care Med

21. Shi S, Qin M, Shen B, Cai Y, Liu T, Yang F et al (2020) Association of Cardiac Injury With Mortality in Hospitalized Patients With COVID-19 in Wuhan, China. In: Association of cardiac injury with mortality in hospitalized patients with COVID-19 in Wuhan. China, JAMA Cardiol

22. Fuchs TA, Brill A, Duerschmied D, Schatzberg D, Monestier M, Myers DD Jr et al (2010) Extracellular DNA traps promote thrombosis. Proc Natl Acad Sci U S A 107:15880-15885

23. Martinod K, Wagner DD (2014) Thrombosis: tangled up in NETs. Blood. 123:2768-2776

24. Mendez-Sanchez N, Valencia-Rodriguez A, Qi X, Yoshida EM, Romero-Gomez M, George J et al (2020) What has the COVID19 pandemic taught us so far? Addressing the problem from a hepatologist's perspective. J Clin Transl Hepatol 8:0024

Publisher's note Springer Nature remains neutral with regard to jurisdictional claims in published maps and institutional affiliations. 